\title{
Stable isotopic records of bleaching and endolithic algae blooms in the skeleton of the boulder forming coral Montastraea faveolata
}

\author{
A. C. Hartmann · J. E. Carilli · R. D. Norris • \\ C. D. Charles · D. D. Deheyn
}

Received: 5 November 2009/Accepted: 31 July 2010/Published online: 15 August 2010

(C) The Author(s) 2010. This article is published with open access at Springerlink.com

\begin{abstract}
Within boulder forming corals, fixation of dissolved inorganic carbon is performed by symbiotic dinoflagellates within the coral tissue and, to a lesser extent, endolithic algae within the coral skeleton. Endolithic algae produce distinctive green bands in the coral skeleton, and their origin may be related to periods of coral bleaching due to complete loss of dinoflagellate symbionts or "paling" in which symbiont populations are patchily reduced in coral tissue. Stable carbon isotopes were analyzed in coral skeletons across a known bleaching event and 12 blooms of endolithic algae to determine whether either of these types of changes in photosynthesis had a clear isotopic signature. Stable carbon isotopes tended to be enriched in the coral skeleton during the initiation of endolith blooms, consistent with enhanced photosynthesis by endoliths. In contrast, there were no consistent $\delta^{13} \mathrm{C}$ patterns directly associated with bleaching, suggesting that there is no unique isotopic signature of bleaching. On the other hand, isotopic values after bleaching were lighter $92 \%$ of the time when compared to the bleaching interval. This marked drop in skeletal $\delta^{13} \mathrm{C}$ may reflect increased kinetic fractionation and slow symbiont recolonization for several years after bleaching.
\end{abstract}

Communicated by Geology Editor Prof. Bernhard Riegl

A. C. Hartmann $(\bowtie)$ - J. E. Carilli · R. D. Norris ·

C. D. Charles - D. D. Deheyn

Scripps Institution of Oceanography, University of California

San Diego, La Jolla, CA 92037, USA

e-mail: achartma@ucsd.edu

Present Address:

J. E. Carilli

Australian Nuclear Science and Technology Organization,

Lucas Heights, NSW 2234, Australia
Keywords Skeletal carbon isotopes - Montastraea faveolata . Coral bleaching $\cdot$ Endolithic algae

\section{Introduction}

Scleractinian corals, such as the Montastraea faveolata studied here, host an array of organisms, including symbiotic dinoflagellates (Klebbs 1884), boring endolithic algae (Lukas 1974; Shashar and Stambler 1992; Le Campion-Alsumard et al. 1995), boring animals (e.g., sipunculid worms, polychaetes, bivalves, and sponges; Holmes et al. 2000), fungi (Golubic et al. 2005), bacteria (Wegley et al. 2004), archaea (Wegley et al. 2004), and viruses (Marhaver et al. 2008). Of these organisms, the major photosynthesizers include symbiotic dinoflagellates, or zooxanthellae, that live in the coral tissue (Klebbs 1884) and endolithic algae that live in the skeleton of both live and dead coral (Lukas 1974).

Zooxanthellae fix carbon, which is translocated to their coral host, providing most, if not all, of the coral's metabolic requirements (Muscatine and Weis 1992). Despite its great success, the coral-zooxanthellae relationship can break down, commonly as a result of light and temperature stress (Glynn 1996). This often results in coral bleaching, recognized by decreased pigmentation or the direct expulsion of dinoflagellate symbionts (Glynn 1996). Bleaching can, but does not always, result in coral mortality.

Endolithic algae, commonly of the genus Ostreobium, can inhabit the skeletons of a variety of coral species (Lukas 1974; summarized in Shashar and Stambler 1992), often forming dense bands (Highsmith 1981). Entire communities of endolithic photoautotrophs (i.e., algae and cyanobacteria) can make up a large proportion of net primary productivity in heads of dead boulder forming corals (Tribollet et al. 2006). Yet, when shaded by live coral tissue, 
endolithic algae receive less than $5 \%$ of ambient light (Rodriguez-Roman et al. 2006) limiting their productivity to $<4 \%$ that of coral symbionts (Shashar and Stambler 1992). Despite this, endoliths can translocate fixed carbon to the tissue of their coral host, and both photosynthesis and translocation may be enhanced during endolith blooms (Schlichter et al. 1995; Fine and Loya 2002).

Dissolved inorganic carbon (DIC) plays a dual role in the coral-algal community, as it is not only fixed by symbionts for nutritional purposes, but it is also the carbon source for the coral's calcium carbonate skeleton. Even when sufficient DIC is available for both processes, changes in the relative amount of photosynthesis may be reflected in the isotopic signature of skeletal carbon (Swart 1983). During photosynthesis, symbionts preferentially utilize forms of DIC containing the light carbon isotope, ${ }^{12} \mathrm{C}$, over the heavier, ${ }^{13} \mathrm{C}$, termed metabolic fractionation (Swart 1983; McConnaughey 1989). The degree of metabolic fractionation is dependent on the amount of photosynthesis occurring at a given point in time, which is governed primarily by irradiance (Fairbanks and Dodge 1979; Pätzold 1984) and sea surface temperature (Fairbanks and Dodge 1979), both of which vary seasonally.

At approximately steady coral calcification rates, the metabolically fractionated $\delta^{13} \mathrm{C}$ signal is passively recorded in the coral skeletal carbonate (McConnaughey 1989). Therefore, skeletal $\delta^{13} \mathrm{C}$ measured along the skeletal growth axis may provide a record of changes in symbiont photosynthesis through time.

During bleaching events, when zooxanthellae photosynthesis is dramatically reduced or non-existent, the degree of metabolic fractionation is expected to drop precipitously, potentially resulting in a depleted $\delta^{13} \mathrm{C}$ signal in the coral skeleton. Indeed, depletion of $\delta^{13} \mathrm{C}$ across known bleaching events has been observed in multiple species such as Montastraea annularis (Porter et al. 1989), Porites spp. (Suzuki et al. 2003), Montipora verrucosa and Porites compressa (Grottoli et al. 2004), and Montipora capitata (Rodrigues and Grottoli 2006).

In theory, photosynthetically driven modulation of the DIC pool available for calcification can be affected by endolithic algae as well as zooxanthellae. When endolithic algae are in high enough abundance (i.e., dense green bands) and near to the site of calcification, they may influence the availability (and as a result the isotopic character) of DIC at the calcification site. This scenario, however, remains a working hypothesis, and the potential role of endolithic algae in modulating the DIC environment near the site of calcification in live coral tissues has yet to be addressed.

Accordingly, the two hypotheses addressed in this study are as follows: (1) The $\delta^{13} \mathrm{C}$ of skeletal aragonite will be depleted beyond the seasonal periodicity within a compression band coincident with bleaching, either as a discrete change or a broad trend within the band; (2) The average $\delta^{13} \mathrm{C}$ of skeletal aragonite will be significantly enriched across endolith bands when compared to nonendolith band areas of coral skeleton due to increased metabolic fractionation caused by increased endolith photosynthesis.

The samples used in the present study provide a unique natural experiment to address two similar hypotheses built on the assumption that the relative amount of photosynthesis drives the isotopic character of the internal DIC pool. In total, 92 coral cores were collected from four sites in the Mesoamerican reef tract between 2006 and 2007 (Carilli et al. 2009a, b). This area suffered widespread bleaching in 1998 (Mcfield 2000; Kramer and Kramer 2000), as did most coral reefs worldwide (Wilkinson 2000). This major bleaching event manifested clearly in the cores reported here as dense compression bands in skeletal X-radiographs, characterized by severely reduced extension rates and increased density: over 4 standard deviations outside the long-term mean (Carilli et al. 2009a, b). Overall, $95 \%$ of the cores contained compression bands coincident with the 1998 bleaching event (Carilli et al. 2009a). Endolithic algae are visually evident in these core samples as well, where they form green bands of variable intensity like those described by Lukas (1974) and Highsmith (1981), providing a unique opportunity to measure the isotopic signature of the coral skeleton during these anomalous periods.

\section{Materials and methods}

\section{Coral collection}

Cores of the scleractinian coral Montastraea faveolata were collected from three sites in the Mesoamerican Reef tract off the coasts of Belize and Honduras (Fig. 1). Divers used a pneumatic drill powered by a shipboard compressor to collect the cores, each approximately $5 \mathrm{~cm}$ in diameter and up to $1.3 \mathrm{~m}$ long. Samples were drilled vertically, parallel to the axis of maximum growth, at 5-6 $\mathrm{m}$ water depth on the forereef in spur-and-groove habitat. Specific drilling locations at each site were chosen away from lagoonal influence or human settlements in order to better represent regional conditions. One or two cores from each site were studied here, representing a small subset of the 92 total cores collected (Carilli et al. 2009a, b). Of the cores examined, Utila1 was collected in July 2007, Utila-2 in June 2006, Cayos Cochinos in July 2006, and Frank's Caye in January 2006.

Dating and isotopic analysis

Slabs approximately $8 \mathrm{~mm}$ thick were cut through the center of each coral core parallel to the axis of growth 


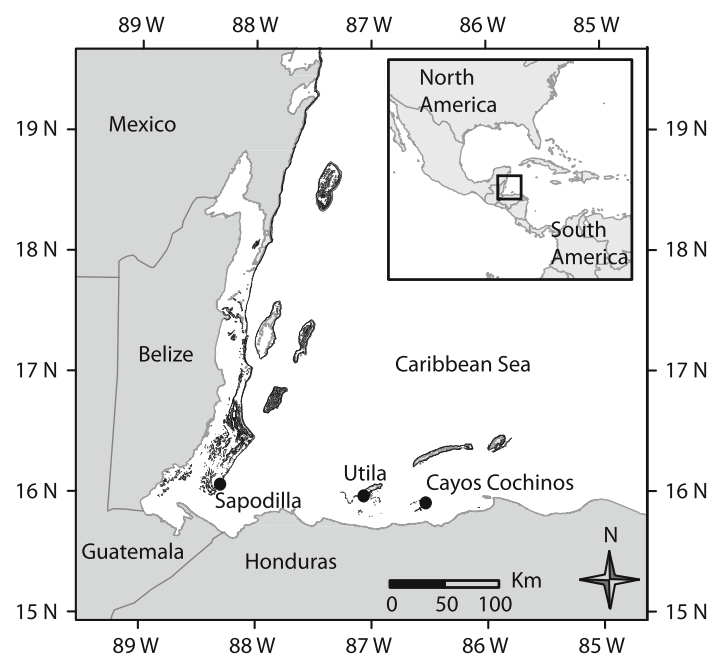

Fig. 1 Location of Utila, Cayos Cochinos, and Sapodilla Cayes sampling sites within the Mesoamerican Reef tract

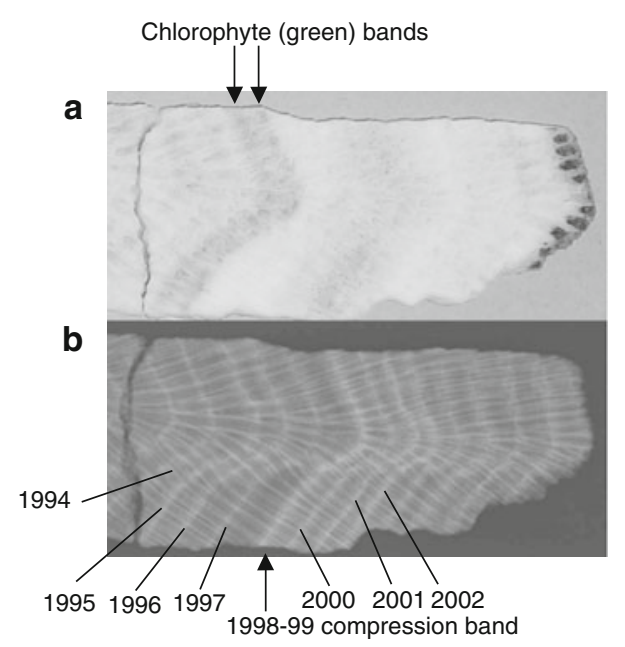

Fig. 2 Plain light photograph (a) and X-radiograph (b) of the same section of core collected from the Utila site in July 2007. The endolith bands in a are formed by endolithic algae and are indicated by black arrows, while the white bands in $\mathbf{b}$ are annual high-density skeletal bands. A compression band is observed here, coincident with the 1998 mass bleaching event

using a double-bladed carbide table saw. Each slab was $\mathrm{X}$-rayed using a Siemens Polyphos 50 at a source-toobject distance of 40 inches and a setting of 63 kilovolts at 5 milliamps/s at Thornton Hospital, UCSD. To assign calendar dates to the cores, the initiation of a high-density band was assigned to be August of a given year coinciding with the observed beginning of high-density band formation in M. faveolata (Cruz-Pinon et al. 2003; Moses and Swart 2006). In the case of the exceptionally high-density, low-extension rate compression bands in these cores, crossdating between multiple cores shows that the timing is coincident with the mass bleaching event of 1998 (see
Fig. 2 for an example core). The initiation of a compression band may not reflect the exact onset of a bleaching event. However, the ubiquity of the compression bands (95\% prevalence), as well as their consistent timing, makes them highly reliable estimators of the timing and duration of the event.

Single cores from Cayos Cochinos and Frank's Caye (in the Sapodilla Cayes) were analyzed along with two cores from Utila (Fig. 1). Approximately 200-300 $\mu \mathrm{g}$ of powdered calcium carbonate was sampled using a small drill press with a $0.5-\mathrm{mm}$ bit at $0.5-$ or $1-\mathrm{mm}$ increments down the growth axis of individual corallites, making sure to stay along corallite walls. Samples were not treated for removal of organic material prior to stable isotope analysis because such pretreatment has been shown to confound stable isotopic measurements, and it is an unnecessary precaution considering that organic matter is not a source of isotopic contamination in samples of coral skeletons (Grottoli et al. 2005).

In this study, endolithic algae showed morphological features under microscopic observations that strongly suggest they belong to the genus Ostreobium, which commonly inhabit coral skeletons. Ostreobium do not calcify (Lukas 1974), thus there is little concern that they contributed calcified material to these samples, or competed for DIC via a calcification process. It is also unlikely that bulk algal material contributed to $\delta^{13} \mathrm{C}$ measurements. The consistent deviations across endolith bands reported here trend in the opposite direction of what would be expected if the isotopically light endolithic algae ( -14.8 to $-12.3 \%$; Titlyanov et al. 2008) were a source of contamination.

Endolithic algae are ubiquitous within coral skeletons and repeatedly rise from low background abundances, forming dense green bands like those studied here. Although the endoliths deep in coral skeletons are not living (e.g., Kanwischer and Wainwright 1967), organic material remains well preserved in massive coral skeletons and thus is clearly observable in these cores (Ingalls et al. 2003).

Multiple sample transects were collected across compression bands (aided by X-radiographs) and endolithic algal bands to assess changes in the isotopic composition of the coral aragonite associated with bleaching and increased endolith activity. Fine-scale isotopic transects were drilled from three cores: Utila-1, Utila-2, and the Cayos Cochinos core at $0.5-\mathrm{mm}$ resolution. The length of these records varied from 10 to 14 years and each included a compression band associated with the 1998 mass bleaching event. Additionally, a long-term record ( $\sim 65$ years) was drilled from a fourth core, Frank's Caye, at 1.0-mm resolution. Four short-term records were used to evaluate the bleaching effect: Utila-1, Utila-2, Cayos Cochinos, and a short portion of the Frank's Caye record. 
Isotopic analyses were performed on a Finnigan MAT 252 stable isotope mass spectrometer attached to a Fairbanks carbonate preparation device. Samples were reacted in a common phosphoric acid bath at $90^{\circ} \mathrm{C}$ for $11 \mathrm{~min}$, a quick reaction time during which organics do not readily hydrolyze. Isotopic ratios are reported in the per mil (\%o) convention, are deviations from the PeeDee Belemnite (PDB) standard, and are reported as:

$\delta^{13} \mathrm{C}=\left[\frac{{ }^{13} \mathrm{C} /{ }^{12} \mathrm{C}_{\text {sample }}-{ }^{13} \mathrm{C} /{ }^{12} \mathrm{C}_{\text {standard }}}{{ }^{13} \mathrm{C} /{ }^{12} \mathrm{C}_{\text {standard }}}\right] \times 1000 \%$

Each run of 40 randomly organized samples included 7 standards of ground Porites sp. coral as a quality control for instrumental precision. Samples were considered to represent before, after, or during the bleaching event or a given endolith bloom as identified by comparing $\mathrm{X}$-radiographs as well as the actual sampled coral slab.

\section{Statistical analyses}

\section{Compression bands}

Linear regression models were fit to each of the four shortterm records and the long-term record in order to detect factors significantly correlated with the skeletal $\delta^{13} \mathrm{C}$ signal over the sampled sections. The model used the continuous variables year, month and month ${ }^{2}$, and the categorical variable compression (within or outside of the compression band). The long-term trend (year) was removed from the $\delta^{13} \mathrm{C}$ values used to evaluate the long-term record due to a significant progressive decline in skeletal $\delta^{13} \mathrm{C}$ over the past 65 years in that core. To evaluate the bleaching effect on skeletal $\delta^{13} \mathrm{C}$ in the four short-term records, no detrending was applied as the progressive isotopic decline was not consistently apparent in these shorter records.

To investigate the influence of bleaching, measured $\delta^{13} \mathrm{C}$ values were pooled into those that were drilled before, during, and after the compression band. Values for each of these time horizons were further categorized by those occurring at isotopic maxima, minima, and all values. Oneto-one comparisons were made for all possible time horizons and all data categorizations. In the case that multiple transects were measured from a single core, all data were considered as independent replicates for further analyses. Tests for significance were computed using permutation tests in $\mathrm{R}$ ( $\mathrm{R}$ Development Core Team).

\section{Cloudiness}

The influence of irradiance on skeletal $\delta^{13} \mathrm{C}$ (via lightdependent changes in zooxanthellate photosynthesis) was evaluated using cloud cover records from the globally gridded Comprehensive Ocean-Atmosphere Data Set maintained by the National Oceanic and Atmospheric Administration. The most robust and long-term cloud data available of the area from which these cores were taken $\left(2 \times 2\right.$-degree pixels centered on $\left.17^{\circ} \mathrm{N} 87^{\circ} \mathrm{W}\right)$ were used to provide monthly average oktas, where oktas are measured as the number of $1 / 8$ ths of sky covered by clouds (i.e., scale ranges from 0 to 8 ). The coral $\delta^{13} \mathrm{C}$ record was matched to the cloudiness record using Analyseries 2.0 (Paillard et al. 1996) to determine whether dating errors in the $\delta^{13} \mathrm{C}$ record could be improved. To assess the magnitude of change in the coral record required for this matching, the difference between the original coral dating and the new dating was calculated. In all but Utila-2, the required shifts were, on average, less than 1 month and were as follows: Utila$1=0.9$ months, Utila $2=2.6$ months, Cayos Cochinos $=0.7$ months, and Frank's Caye $=0.6$ months. When considered, these shifts improved the linear correlation between the records from an average $r^{2}$ value of -0.13 to -0.30 . The correlation between skeletal $\delta^{13} \mathrm{C}$ and cloudiness was evaluated in Analyseries 2.0, and statistical significance was determined via a simple linear model in $\mathrm{R}$.

\section{Endolith bands}

Skeletal isotope values from the Frank's Caye core were used to evaluate the influence of endolith blooms on skeletal $\delta^{13} \mathrm{C}$ and included 12 endolith bands spaced throughout the core, none of which exceeded $3 \mathrm{~mm}$ in width. Endolithic algae live just below the tissue in coral skeletons, growing upward with the coral (Lukas 1974), and driven by light limitation thresholds (Fine and Loya 2002; Magnusson et al. 2007). Endoliths in live Porites corals have been observed to grow no deeper than $5 \mathrm{~mm}$ below the tissue layer (Le Campion-Alsumard et al. 1995) and at a similar skeletal depth in Montipora monasteriata corals (Magnusson et al. 2007); it is assumed here that endoliths in $M$. faveolata have a similar limit.

Due to the nature of core samples, there was no way to determine exactly at what depth individual endolith bands grew in relation to the live tissue. Therefore, the influence of endolith photosynthesis on skeletal $\delta^{13} \mathrm{C}$ values was evaluated over the $0-5 \mathrm{~mm}$ range of possible algal growth locations below the site of calcification. To do this, scenarios of endolith band locations from 0 to $5 \mathrm{~mm}$ below the calcification site were considered at $1-\mathrm{mm}$ increments (Fig. 3a). Data were grouped by $\delta^{13} \mathrm{C}$ values within the 'zone of influence', that is area of skeleton that was calcifying while an endolith band was forming below, and those outside of the zone of influence for each scenario. For example, the 4-mm scenario assumes that the site of calcification was four $\mathrm{mm}$ above the endolith band. Thus, the skeletal $\delta^{13} \mathrm{C}$ values considered within the zone of 
influence for this scenario began four $\mathrm{mm}$ above the bottom of the endolith band. The three mm width of the scenario corresponds to the width of the endolith band.

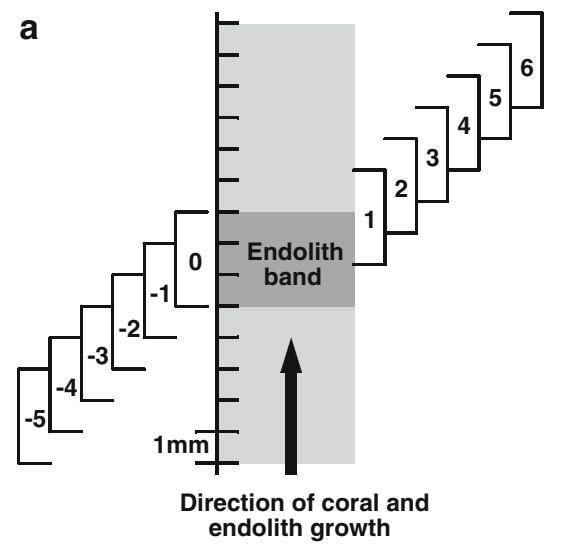

b

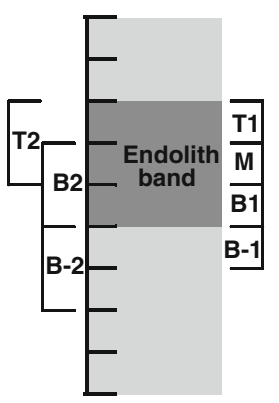

Fig. 3 a A schematic example of a section the Frank's Caye core that includes a 3-mm-wide endolith band. Each bracket represents a single scenario, or 'zone of influence', and its corresponding number denotes the distance between the endolith band and the site of calcification (e.g., 0-mm scenario assumed that endoliths grew adjacent to the coral tissue, $1-\mathrm{mm}$ scenario assumed that endoliths lived $1 \mathrm{~mm}$ below the coral tissue and so on), and 0-5 represent possible endolith growth locations with respect to the live tissue, while 6 is unlikely because it is deeper than any published accounts of endolith growth locations, and -1 through -5 are impossible growth locations used as pseudo controls, since this would assume the algae were growing before the coral calcified. Thus, the skeletal $\delta^{13} \mathrm{C}$ values compared within and outside the endolith band in each scenario include those that would have been influenced by endolith photosynthesis for one respective algal growth location. The width of each scenario and its corresponding endolith band are equal because it was assumed that the endolith band extended across an equal amount of skeletal growth. b The scenarios in a contain overlapping values and thus the application of the seven scenarios in $\mathbf{b}$ assists in differentiating between regions within the endolith band. Scenario "B-2" contains only the two points below each endolith band, scenario "B-1" contains only the single point below each band, "B1" only the bottom point within each band, "B2" the bottom two points within each band, "M" the middle point, "T2" the top two points within the band, and "T1" the single top point within the band
As pseudo controls, a 6-mm scenario, corresponding to a depth location at which the endoliths would likely die off, and five scenarios $(-1$ to -5$)$ of skeleton calcified before the endolith band existed were included as well (Fig. 3a). Statistical significance of the influence of the endolithic bands was tested using a linear regression model that included the continuous variables year and month, as well as the categorical variables compression (within or outside of the compression band), and endolith (within or outside of an endolith band's zone of influence).

A limitation to using the above technique was that all of the endolith growth location scenarios intrinsically include point(s) that overlap with other scenarios. Thus, single and grouped skeletal $\delta^{13} \mathrm{C}$ samples within and below the endolith bands (example for $0-\mathrm{mm}$ scenario given in Fig. 3b) were analyzed as well in order to remove data overlap between scenarios. Each sample(s) within or below the endolith bands (e.g., Fig. 3b: B-2, B-1, B1.) was separately evaluated using a linear regression model that included the continuous variables year and month, as well as the categorical variables compression (within or outside of the compression band), and endolith sample (e.g., Fig. 3b: B-2).

\section{Results}

\section{Compression bands}

A significant $(P<0.001)$ long-term negative trend was evident in the Frank's Caye core (Fig. 4) and accounted for $21 \%$ of the isotopic variability in the record. In addition to the long-term trend, skeletal $\delta^{13} \mathrm{C}$ values also correlated with the month of the year $(P<0.01)$, but explained very little of the variability $(\sim 1.4 \%)$.

Linear regressions of the short-term records showed that skeletal $\delta^{13} \mathrm{C}$ values within the compression band in the
Fig. $4 \delta^{13} \mathrm{C}$ record from Frank's Caye Core from 1940 to 2006. Also shown is the shortterm record sampled at higher frequency that was extracted from this record

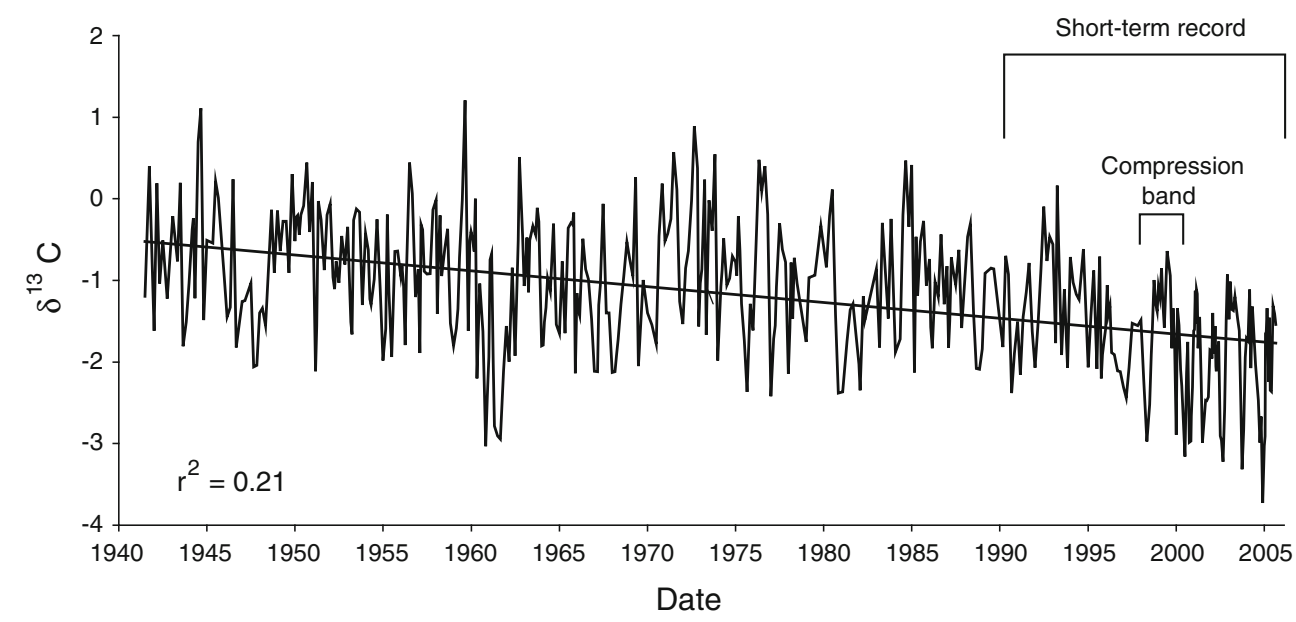


Utila-1 record were heavier $(P<0.001)$ than those outside (Fig. 5a), $\delta^{13} \mathrm{C}$ decreased $(P<0.05)$ through time (variable: year) in the Cayos Cochinos record (Fig. 5d), and no variable showed a significant correlation in the Utila- 2 or Frank's Caye records (Fig. 5b, c, respectively).

Fine-scale analyses of the long-term Frank's Caye core detected no difference between isotopic values measured before and during the compression band, but the values after the compression band were significantly lighter than those before $(P<0.001)$. This depletion in $\delta^{13} \mathrm{C}$ after the bleaching event was also found in comparisons using the four short-term records (Cayos Cochinos, Frank's Caye, Utila-1, and Utila-2) (Table 1). In the cores from Cayos Cochinos and Frank's Caye, maxima after the compression band were significantly lighter than maxima before the band ( $P=0.02$ and $P=0.003$, respectively). In those two

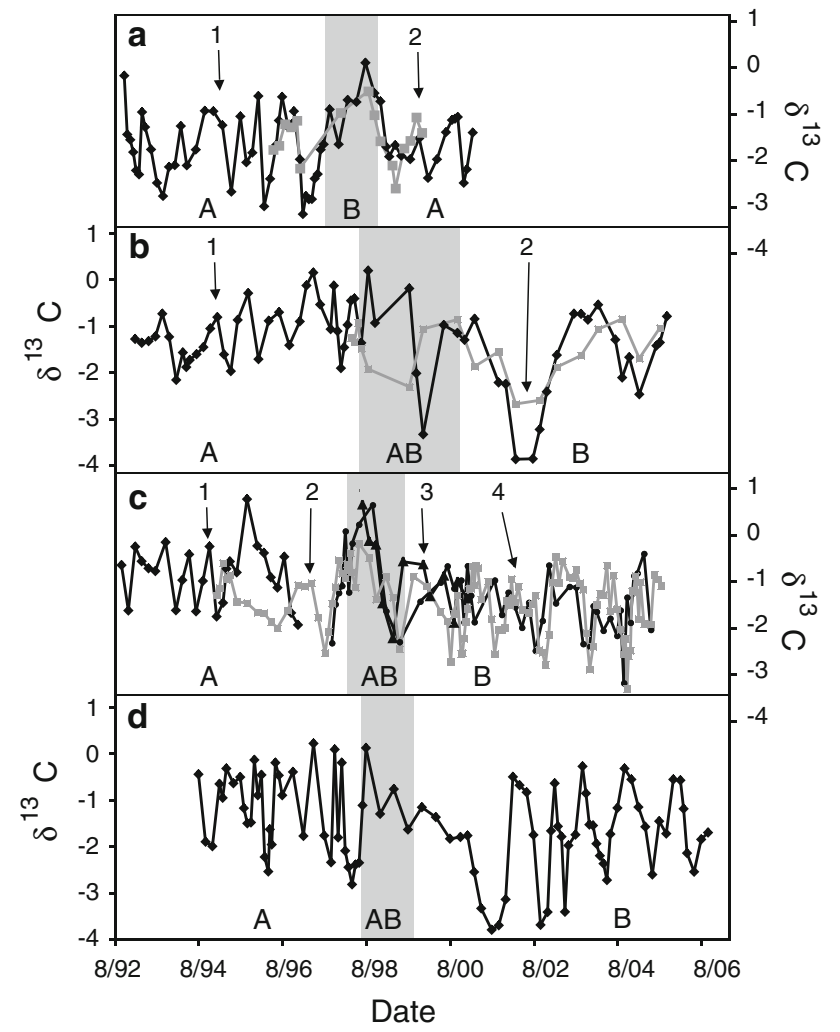

Fig. $5 \delta^{13} \mathrm{C}$ values across compression bands (gray vertical bars) due to the 1998 mass bleaching event from four cores taken from three different sites in the Mesoamerican Reef: a Utila-1, b Utila-2, c Frank's Caye, d Cayos Cochinos. Numbered arrows denote distinct measurement transects, which are shown in gray and black lines $(\mathbf{a}, \mathbf{b}$, c). In the Frank's Caye core (c), transects in addition to those included in the long-term record (Fig. 4) are shown. Capital letters ( $A$ and $B$ ) denote statistically significant differences between all isotopic values pooled for each time horizon (before compression band, within compression band, after compression band). For example, in $\mathbf{b}$, there is a significant difference between all of the values before the compression band and all of the values after, but no difference between those before vs. within the compression band or those after vs. those within the compression band. These data are also shown in Table 1 cores, as well as Utila-2, the minima of skeletal $\delta^{13} \mathrm{C}$ after the compression band were also significantly lighter ( $P=0.04, P=0.005$ and $P=0.035$, respectively). When all isotopic values before and after the compression band were compared, Cayos Cochinos, Frank's Caye, and Utila2 all show significant depletion after the bleaching event ( $P=0.01, P=0.02$ and $P=0.004$, respectively), but no significant differences during the event. Utila-1 was an anomaly within this group, with a significantly heavier signal inside $(P<0.05)$ the compression band and no differences before or after.

Heavier isotopic values were found at the beginning of compression bands in four transects (Fig. 5 b1, b2, c3, d), while lighter values were observed in three others (Fig. 5 a1, a2, c2). Of all comparisons of regions outside to those inside a compression band (Table 1), the compression band values were heavier $83 \%$ of the time, yet only 5 of 36 comparisons were statistically significant. In $83 \%$ of the comparisons, values after the compression band were lighter than those before, and 8 of 12 were significant. Additionally, isotopic values after the band were lighter

Table 1 Pairwise comparisons of skeletal $\delta^{13} \mathrm{C}$ values across the 1998 bleaching event utilizing values before ("Before"), during ("Compression"), and after ("After") the bleaching event, as well as before and after pooled ("Non-Compression")

\begin{tabular}{cllll}
\hline & $\begin{array}{l}\text { Compression } \\
\text { vs. before }\end{array}$ & $\begin{array}{l}\text { After vs. } \\
\text { compression }\end{array}$ & $\begin{array}{l}\text { After vs. } \\
\text { before }\end{array}$ & $\begin{array}{l}\text { Compression vs. } \\
\text { non-compression }\end{array}$ \\
\hline Difference in maximum & $\delta^{13}$ C values (\%o) & \\
Cayos & -0.23 & -0.36 & $-0.59^{*}$ & -0.95 \\
Frank's & +0.39 & $-0.90^{*}$ & $-0.51^{*}$ & $+0.76^{*}$ \\
Utila-1 & +0.61 & -0.99 & -0.38 & +0.61 \\
Utila-2 & +0.10 & -0.37 & -0.27 & +0.29 \\
Difference in minimum $\delta^{13} \mathrm{C}$ values $(\%)$ & \\
Cayos +0.82 & -1.65 & $-0.84^{*}$ & +0.03 \\
Frank's -0.73 & +0.01 & $-0.72^{*}$ & -0.27 \\
Utila-1 & +0.97 & -0.62 & +0.34 & +4.30 \\
Utila-2 & +0.77 & -2.24 & $-1.46^{*}$ & +0.77 \\
Difference in all $\delta^{13} \mathrm{C}$ values $(\%)$ & & \\
Cayos & +0.37 & -0.91 & $-0.54^{*}$ & +0.68 \\
Frank's & +0.12 & -0.43 & $-0.32^{*}$ & +0.35 \\
Utila-1 & $+1.09 *$ & $-0.92^{*}$ & 0.17 & $+1.01^{*}$ \\
Utila-2 & -0.05 & -0.56 & $-0.61^{*}$ & +0.15 \\
\hline
\end{tabular}

Comparisons for each time period were performed three ways: (1) all isotopic maxima in the sinusoidal time-series; (2) all isotopic minima in the sinusoidal time-series; (3) all isotopic values. The data in the table represent the difference, on average, of skeletal $\delta^{13} \mathrm{C}$ values of the first period when compared to the second (i.e., Compression vs. Before $(\%)=-0.23$ indicates that the (maximum) values in the compression band are on average $0.23 \%$ lighter than those before the compression band. $P$-values were calculated for each comparison using a permutation test and asterisks denote statistical significance $(P<0.05)$ 


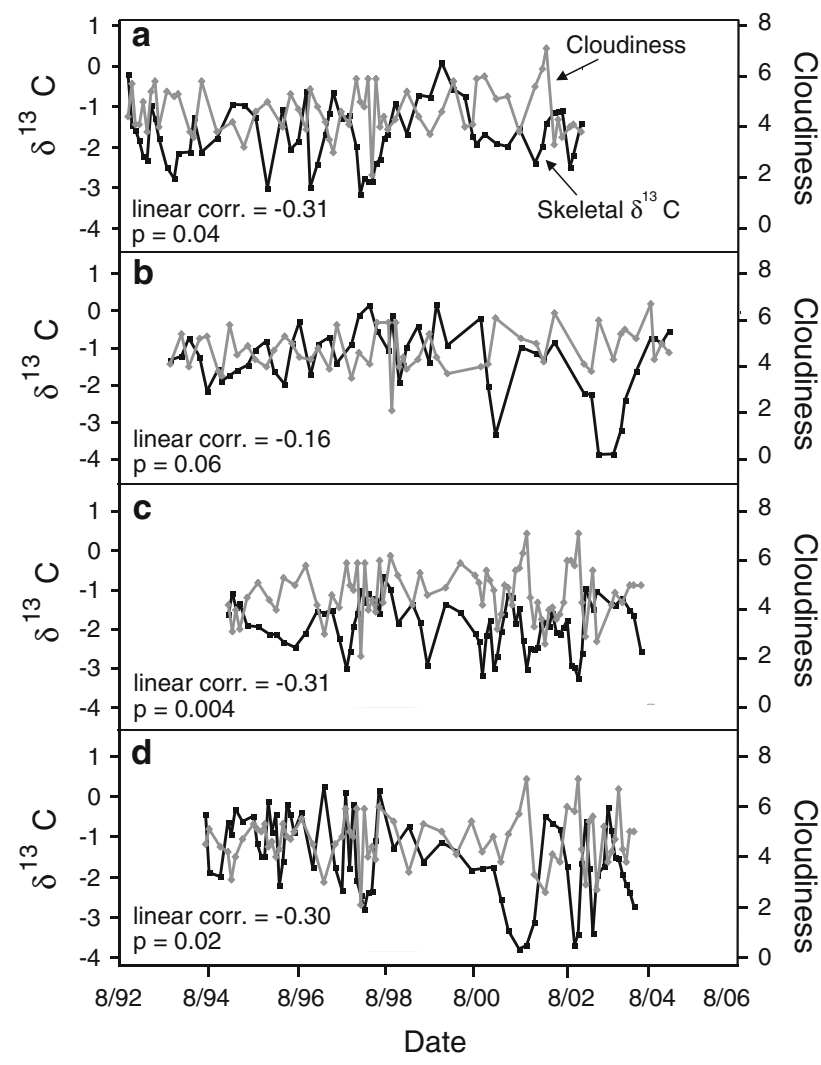

Fig. 6 Time series of monthly average cloudiness (as monthly averaged oktas) and skeletal $\delta^{13} \mathrm{C}$ measurements from a Utila-1, b Utila-2, c Frank's Caye, and d Cayos Cochinos short-term record. The records in black are those of skeletal $\delta^{13} \mathrm{C}$ measurements, while those in gray are standardized cloudiness. The linear correlation and associated $P$-values between the two records are reported for each record

$92 \%$ of the time when compared to values within the compression bands.

\section{Cloudiness}

Negative correlations between cloudiness and skeletal $\delta^{13} \mathrm{C}$ were found in all cores examined here (Fig. 6) and three of the four records were significantly correlated $(P<0.05)$, while the fourth was marginally significant $(P=0.06)$.

\section{Endolith bands}

The endolith bands studied here followed the growth contours of the coral skeleton. No endolith band was more than $3 \mathrm{~mm}$ in width-less than half the $\sim 8 \mathrm{~mm}$ width of annual bands in these cores. Considering the narrow width of endolith bands, along with the observation that blooms appear no more than $5 \mathrm{~mm}$ below the tissue layer, it is likely that these blooms only lasted a few months.

The variables year and month correlated significantly with the skeletal $\delta^{13} \mathrm{C}$ values $(P<0.001$ and $P<0.01$,

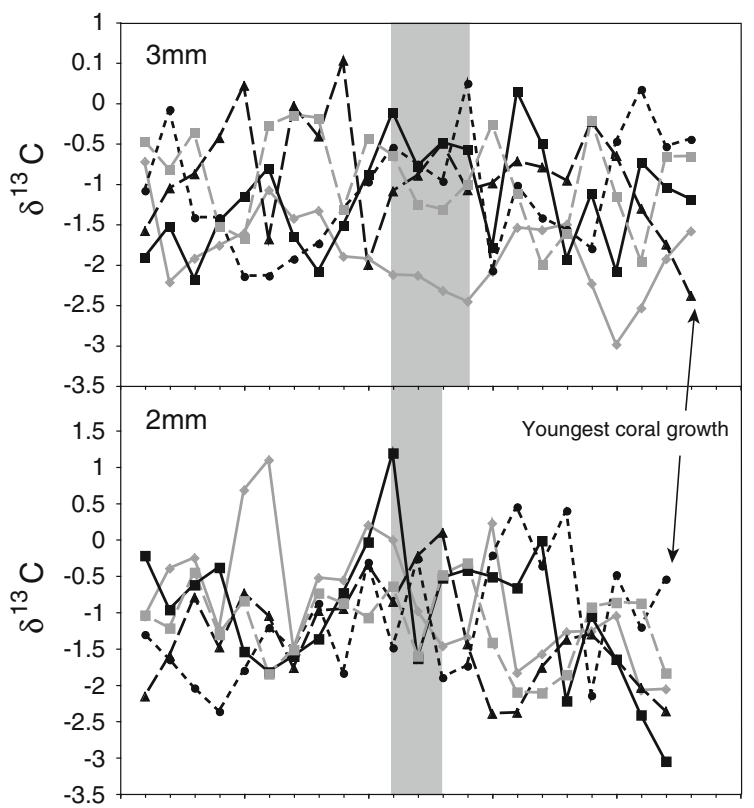

Overlapped transects across endolith bands throughout core ( $\mathrm{mm}$ increments)

Fig. 7 Isotopic record across 10 endolith bands (gray bars) sampled throughout the core and overlaid on one another for comparison. Bands with widths of $3 \mathrm{~mm}$ (top) and $2 \mathrm{~mm}$ (bottom) are shown, each surrounded by $10 \mathrm{~mm}$ of measurements before and after the bands. The prevailing direction of coral growth is from left to right, with the youngest skeletal growth regions falling on the right as indicated

respectively) in all of the endolith growth location scenarios outlined in Fig. 3. Conversely, only in the 0-mm endolith growth scenario (i.e., endolith band growing directly adjacent to the calcification site), was there a significant correlation between the presence of an endolith band and the skeletal $\delta^{13} \mathrm{C}$ signal $(P<0.05)$, suggesting that endolith bands formed close to the underside of the coral tissue layer. $\delta^{13} \mathrm{C}$ values within endolith bands in the 0-mm scenario were heavier than those outside (Fig. 7).

Fine-scale analysis of the individual points and groups of points within the endolith bands (Fig. 3b) found that in bands wider than $2 \mathrm{~mm}$, only the lowest $1-2 \mathrm{~mm}$ of the band showed a significant $(P<0.05)$ correlation with skeletal $\delta^{13} \mathrm{C}$, the lowermost $1 \mathrm{~mm}$ being enriched by an average of $0.5 \%$, and the bottom $2 \mathrm{~mm}$ being enriched by $0.4 \%$ on average.

\section{Discussion}

Long-term trends

The long-term negative trend over time in the Frank's Caye core (Fig. 4) was at least partially driven by the Suess Effect, the progressive isotopic depletion of atmospheric $\mathrm{CO}_{2}$ due to fossil fuel emissions, which are depleted in ${ }^{13} \mathrm{C}$ (Keeling 1979). $\delta^{13} \mathrm{C}$ measurements from the calcium 
carbonate of sclerosponges provide a reference for the $\delta^{13} \mathrm{C}$ of seawater DIC because carbon isotope fractionation does not occur during calcium carbonate formation in this organism (Böhm et al. 1996). The sclerosponge record displays a steady decrease in $\delta^{13} \mathrm{C}$ over the last decade in the Caribbean Sea and a total decrease of $\sim 0.5 \%$ from 1940 to 1990 (Böhm et al. 1996). In the Frank's Caye Core, skeletal $\delta^{13} \mathrm{C}$ decreased by $\sim 0.7 \%$ over the same time period, suggesting that the coral skeleton was slightly depleted in the heavy isotope compared to the isotopic composition of seawater DIC, which is consistent with past reports (e.g., McConnaughey 1989).

The Suess Effect was not consistently observed in the four short-term records. Only in the Cayos Cochinos record, there was a significant decrease in isotopic values through time $(P<0.05)$. The Suess Effect is likely masked by other isotopic signals, such as those connected to bleaching, or may be obscured by the relatively short length of these records (15-20 years).

Hypothesis 1: $\delta^{13} \mathrm{C}$ depletion upon the onset of compression bands

Isotopic profiles across compression bands coincident with the 1998 bleaching event did not consistently show depletions in $\delta^{13} \mathrm{C}$, contrary to past studies (e.g., Porter et al. 1989; Carriquiry et al. 1994; Suzuki et al. 2003; Grottoli et al. 2004; Rodrigues and Grottoli 2006). Both enrichment and depletion of skeletal $\delta^{13} \mathrm{C}$ occurred at the onset of compression bands in the four cores studied here (Fig. 5). Leder et al. (1991) observed similar inconsistencies in $\delta^{13} \mathrm{C}$ across skeleton laid down following a bleaching event in M. annularis. However, the water depth of sample collection, known to influence the $\delta^{13} \mathrm{C}$ signal (Weber et al. 1976; McConnaughey 1989), was not held constant in the Leder et al. (1991) study. In the present study, all coral cores were collected from the same water depth and similar observations to Leder et al. (1991) were made, suggesting that skeletal $\delta^{13} \mathrm{C}$ is not a reliable bleaching proxy in M. faveolata.

Taken together, the data presented here show that isotopic values within compression bands were heavier than those before or after. Anomalously heavy values across compression bands reported by Leder et al. (1991) and in the present study may be explained by an abrupt decline in kinetic fractionation due to slowed calcification after bleaching. During calcification, ${ }^{12} \mathrm{CO}_{2}$ reacts more quickly than ${ }^{13} \mathrm{CO}_{2}$, a phenomenon termed kinetic isotope fractionation (McConnaughey 1989). Therefore, based on kinetic effects, the amount of ${ }^{13} \mathrm{C}$ precipitated should increase as the rate of calcification decreases. Indeed, enriched $\delta^{13} \mathrm{C}$ values during periods of slow calcification were observed in Porites lutea collected in Thailand (Allison et al. 1996). The significantly reduced post-bleaching calcification of the corals studied here is consistent with reports of slow growth after bleaching in Porites spp. (Allison et al. 1996; Suzuki et al. 2003), M. annularis (Goreau and Macfarlane 1990), Montipora capitata and Porites compressa (Rodrigues and Grottoli 2006). While it is likely that isotopic depletion due to the metabolic effects of zooxanthellae loss would be evident if there was no interruption in growth rate post-bleaching, isotopic enrichments suggest that reduced kinetic fractionation due to slow calcification overwhelmed any metabolic modulation of skeletal $\delta^{13} \mathrm{C}$.

The variability in post-bleaching isotopic signals (Fig. 5) likely reflects differential recovery of individual colonies after the event, primarily in terms of calcification and zooxanthellae repopulation rates. Changes in calcification and photosynthesis rates after bleaching may have shifted the degree to which the isotopic composition of DIC within a given coral head was driven by kinetic versus metabolic effects. Here, $93 \%$ of the transitions from the compression band back to "normal" calcification showed a decrease in $\delta^{13} \mathrm{C}$, with three of the four cores having significant isotopic depletion after the band when compared to before. This suggests that kinetic fractionation increased again after the bleaching event, leading to less incorporation of ${ }^{13} \mathrm{C}$ into the skeleton. Authors have attempted to remove kinetic effects from skeletal $\delta^{13} \mathrm{C}$ records through modeling (Heikoop et al. 2000; Adkins et al. 2003; Omata et al. 2005), but such an assessment was beyond the scope of this study.

In addition to kinetic and metabolic effects, other factors can drive the isotopic signal in coral skeletons. These include seasonal changes in DIC of the surrounding seawater (Swart et al. 1996); the isotopic composition of heterotrophically acquired energy sources (e.g., zooplankton; Grottoli 2002; Grottoli et al. 2006; Rodrigues and Grottoli 2006); and selective sequestration of ${ }^{12} \mathrm{C}$ in gametes (summarized by Swart et al. 1996). Relevant to the issue examined here is evidence that corals can respond to bleaching by increasing heterotrophic carbon acquisition (Grottoli et al. 2006). Increased heterotrophy on isotopically depleted food sources (e.g., zooplankton) can deplete the skeletal $\delta^{13} \mathrm{C}$ signal, an effect that drives the skeletal DIC pool $\delta^{13} \mathrm{C}$ in the same direction as the loss of metabolic fractionation by zooxanthellae (Grottoli 2002; Grottoli et al. 2006; Rodrigues and Grottoli 2006). Heterotrophic plasticity has not been examined in $M$. faveolata, but it is plausible that increased feeding alone or in synergy with loss of zooxanthellae can drive down the $\delta^{13} \mathrm{C}$ signal during bleaching and recovery. Therefore, there could be at least two plausible explanations for why isotopic values were depleted after the compression band: increased kinetic fractionation which exposes decreased metabolic fractionation post-bleaching; and/or an increase in heterotrophic feeding to make up for the lack of fixed carbon from zooxanthellae. 
Physical factors such as changes in temperature and light availability, as well as the biological responses to those factors, determine whether and when corals bleach, as well as the severity of the episode (Glynn 1996). Decreases in light intensity are thought to decrease photosynthesis as well as the degree of metabolic fractionation during calcification, driving positive correlations between irradiance and skeletal $\delta^{13} \mathrm{C}$ (Heikoop et al. 2000 and references contained therein). Indeed, negative correlations between skeletal $\delta^{13} \mathrm{C}$ and cloud cover (less irradiation) reported here suggest that metabolic fractionation by photoautotrophs within coral colonies is responsible for driving $\delta^{13} \mathrm{C}$ to an appreciable extent. Yet, the marginal significance observed in one of the four cores, as well as the relatively low correlation coefficient in all four, further supports the notion that there are multiple factors influencing the skeletal $\delta^{13} \mathrm{C}$ values measured here in addition to metabolic fractionation.

The degree to which each coral head initially bleached likely determined the relative influences of many factors influencing skeletal $\delta^{13} \mathrm{C}$ values thereafter (e.g., kinetic and metabolic fractionation, heterotrophy), likely causing the variable isotopic responses between cores. Inconsistent reports of the $\delta^{13} \mathrm{C}$ response to bleaching across genera suggest that species-specific responses may also explain why skeletal $\delta^{13} \mathrm{C}$ depletions are not consistently observed (e.g., Porites, Montipora; Porter et al. 1989; Suzuki et al. 2003; Grottoli et al. 2004; Rodrigues and Grottoli 2006).

Overall, there is no clear isotopic signal of the severe and widespread bleaching event in M. faveolata. These results support past findings that metabolic effects are one of many influences on the $\delta^{13} \mathrm{C}$ signal in coral skeletons, but the confounding effects of additional drivers reduce the utility of $\delta^{13} \mathrm{C}$ as a bleaching proxy.

\section{Hypothesis 2: $\delta^{13} \mathrm{C}$ enrichment across endolith bands}

The skeletal $\delta^{13} \mathrm{C}$ values corresponding to endolith growth adjacent to the site of calcification $(0-\mathrm{mm}$ scenario in Fig. 3a) in the Frank's Caye core were significantly enriched. Finer-scale examination of $\delta^{13} \mathrm{C}$ values within and around the endolith bands reveal that those values at the bottom of the endolith band showed the greatest enrichment. Taken together, these results suggest that endoliths in M. faveolata probably bloom adjacent to the coral tissue layer and enrich the coral's internal pool of DIC in ${ }^{13} \mathrm{C}$. This is consistent with the hypothesis that the endoliths actively withdraw ${ }^{12} \mathrm{C}$ from the coral's internal DIC pool. Still it is unclear why a trend of enriched $\delta^{13} \mathrm{C}$ was not observed throughout the entire band. It is speculated here that blooms (in particular during the intense growth phase) are ephemeral in time despite being several $\mathrm{mm}$ thick in certain places within the skeleton.
Endolithic algae residing in $M$. faveolata have been associated with high concentrations of brucite $\left(\mathrm{Mg}(\mathrm{OH})_{2}\right)$ crystals (Buster and Holmes 2006; Nothdurft et al. 2005). Brucite does not contain carbon and thus would not affect carbon fractionation during calcification or influence the measured carbon isotope signature in adjacent skeletal formations. While brucite precipitation may fractionate oxygen and therefore influence the character of $\delta^{18} \mathrm{O}$ available for calcification, it is reasonable to conclude that brucite formation has little or no influence on skeletal $\delta^{13} \mathrm{C}$ because it lacks carbon. Smith et al. (2006) found heterogeneity in $\mathrm{Sr} / \mathrm{Ca}$ ratios across skeletal formations in $M$. faveolata, which, like $\delta^{13} \mathrm{C}$, cannot necessarily be explained by brucite precipitation, but instead likely occurs due to post-deposition thickening of the skeleton, underscoring the need to sample accurately along corallite walls. However, the clear existence of annual cycles in the records described here (e.g., Fig. 4) indicates that the sampling did indeed proceed along the corallite walls and did not include significant amounts of younger material which may have masked this signal.

These results suggest that more attention should be paid to the influence of endolithic photosynthesizers on the skeletal $\delta^{13} \mathrm{C}$ signal because of their potential effect on isotopic records. Furthermore, there is a need to better understand the ecological role of endolithic algae in the coral biome, as it appears that they may be a larger sink of internal DIC than previously recognized. Of particular importance is the interaction of the endolith blooming phenomena with coral bleaching or paling (Carilli et al. 2010). Endolith growth, photosynthesis, and translocation can increase after bleaching (Fine and Loya 2002; Rodriguez-Roman et al. 2006), though it is unclear if the algae provide a sufficient food source to increase the coral's survival after the loss of symbionts. Further work is needed to elucidate the drivers of endolith blooming as well as the potential for these organisms to provide fixed carbon to their host, both during "normal" coral growth and times of stress such as bleaching. A more comprehensive understanding of all potential mechanisms that confer bleaching resilience to corals will be instrumental in predicting the health of coral communities of the future under the lens of global climate change.

Acknowledgments The authors thank M. Carilli, B. Erisman, K. Hughen, E. Kisfaludy, N. Prouty, and S. Walsh for assistance with coral core collection and D. Richter for help with isotopic analyses. M. Roldan X-rayed the cores at Thornton Hospital. M. Latz, J. Leichter, and J. Jackson provided helpful comments on earlier drafts of this manuscript. This work was supported by the PADI Foundation, B. Katz, and two anonymous donors (JEC). This material is based upon work supported by the National Science Foundation under Grant No. 0333444 and the Graduate Research Fellowship (ACH). 
Open Access This article is distributed under the terms of the Creative Commons Attribution Noncommercial License which permits any noncommercial use, distribution, and reproduction in any medium, provided the original author(s) and source are credited.

\section{References}

Adkins JF, Boyle EA, Curry WB, Lutringer A (2003) Stable isotopes in deep-sea corals and a new mechanism for "vital effects". Geochim Cosmochim Acta 67:1129-1143

Allison N, Tudhope AW, Fallick AE (1996) Factors influencing the stable carbon and oxygen isotopic composition of Porites lutea coral skeletons from Phuket, South Thailand. Coral Reefs $15: 43-57$

Böhm F, Joachimski MM, Lehnert H, Morgenroth G, Kretschmer W, Vacelet J, Dullo W-C (1996) Carbon isotope records from extant Caribbean and South Pacific sponges: Evolution of $\delta^{13} \mathrm{C}$ in surface water DIC. Earth Planet Sci Lett 139:291-303

Buster NA, Holmes CW (2006) Magnesium content within the skeletal architecture of the coral Montastraea faveolata: locations of brucite precipitation and implications to fine-scale data fluctuations. Coral Reefs 25:243-253

Carilli J, Norris RD, Black B, Walsh S, McField M (2009a) Local stressors reduce coral resilience to bleaching. PloS One 4:e6324

Carilli J, Norris RD, Black B, Walsh S, McField M (2009b) Centuryscale records of coral growth rates indicate that local stressors reduce coral thermal tolerance threshold. Global Change Biol 16:1247-1257

Carilli J, Godfrey J, Norris R, Sandin S, Smith J (2010) Periodic endolithic algal blooms in Montastraea faveolata corals may represent periods of low-level stress. Bull Mar Sci: Fast-track publication

Carriquiry JD, Risk MJ, Schwarcz HP (1994) Stable isotope geochemistry of corals from Costa Rica as proxy indicator of the El Nino/Southern Oscillation (ENSO). Geochim Cosmochim Acta 58:335-351

Cruz-Pinon G, Carricart-Ganivet JP, Espinoza-Avalos J (2003) Monthly skeletal extension rates of the hermatypic corals Montastraea annularis and Montastraea faveolata: Biological and environmental controls. Mar Biol (Berl) 143:491-500

Fairbanks RG, Dodge RE (1979) Annual periodicity of the oxygen-18 to oxygen-16 and carbon-13 to carbon-12 ratios in the coral Montastrea-annularis. Geochim Cosmochim Acta 43:1009-1020

Fine M, Loya Y (2002) Endolithic algae: an alternative source of photoassimilates during coral bleaching. Proc R Soc Lond B 269:1205-1210

Glynn PW (1996) Coral Bleaching: facts, hypotheses and implications. Global Change Biol 2:495-509

Golubic S, Radtke G, Le Campion-Alsumard T (2005) Endolithic fungi in marine ecosystems. Trends Microbiol 13:229-235

Goreau TJ, Macfarlane AH (1990) Reduced growth rate of Montastrea annularis following the 1987-88 coral-bleaching event. Coral Reefs 8:211-215

Grottoli AG (2002) Effect of light and brine shrimp on skeletal delta C-13 in the Hawaiian coral Porites compressa: A tank experiment. Geochim Cosmochim Acta 66:1955-1967

Grottoli AG, Rodrigues LJ, Juarez C (2004) Lipids and stable carbon isotopes in two species of Hawaiian corals, Porites compressa and Montipora verrucosa, following a bleaching event. Mar Biol 145:621-631

Grottoli AG, Rodrigues LJ, Matthews KA, Palardy JE, Gibb OT (2005) Pre-treatment effects on coral skeletal delta C-13 and delta O-18. Chem Geol 221:225-242
Grottoli AG, Rodrigues LJ, Palardy JE (2006) Heterotrophic plasticity and resilience in bleached corals. Nature 440:1186-1189

Heikoop JM, Dunn JJ, Risk MJ, Schwarcz HP, McConnaughey TA, Sandeman IM (2000) Separation of kinetic and metabolic isotope effects in carbon-13 records preserved in reef coral skeletons. Geochim Cosmochim Acta 64:975-987

Highsmith RC (1981) Lime-boring algae in hermatypic coral skeletons. J Exp Mar Biol Ecol 55:267-281

Holmes KE, Edinger EN, Hariyadi, Limmon GV, Risk MJ (2000) Bioerosion of live massive corals and branching coral rubble on Indonesion coral reefs. Mar Pollut Bull 40:606-617

Ingalls A, Lee C, Druffel ERM (2003) Preservation of organic matter in mound-forming coral skeletons. Geochim Cosmochim Acta 67:2827-2841

Kanwischer JW, Wainwright SA (1967) Oxygen balance in some reef corals. Biol Bull 135:141-148

Keeling CD (1979) The Suess Effect: ${ }^{13}$ Carbon- ${ }^{14}$ Carbon interactions. Environ Int 2:229-300

Klebbs G (1884) Ein kleiner Beitrag zur Kenntnis der Peridineen. Bot Ztg 10:46-47

Kramer PA, Kramer PR (2000) Transient and lethal effects of the 1998 coral bleaching event on the Mesoamerican reef system. Proc 9th Int Coral Reef Symp 2:1175-1180

Le Campion-Alsumard T, Golubic S, Hutchings P (1995) Microbial endoliths in skeletons of live and dead coral: Porites lobata (Moorea, French Polynesia). Mar Ecol Prog Ser 117:149-157

Leder JJ, Szmant AM, Swart PK (1991) The effect of prolonged bleaching on skeletal banding and stable isotopic composition in Montastrea-annularis preliminary observations. Coral Reefs 10:19-27

Lukas KJ (1974) 2 species of the chlorophyte genus Ostreobium from skeletons of Atlantic and Caribbean reef corals. J Phycol 10:331-335

Magnusson A, Fine M, Kuhl M (2007) Light microclimate of endolithic phototrophs in the scleractinian corals Montipora monasteriata and Porites cylindrical. Mar Ecol Prog Ser 332:119-138

Marhaver KL, Edwards RA, Rowher F (2008) Viral communities associated with healthy and bleaching corals. Environ Microbiol 10:2277-2286

McConnaughey T (1989) C-13 and O-18 isotopic disequilibrium in biological carbonates.1. Patterns. Geochim Cosmochim Acta 53:151-162

McField MD (2000) Influence of disturbance on coral reef community structure in Belize. Proc 9th Int Coral Reef Symp 1:63-68

Moses CS, Swart PK (2006) Stable isotope and growth records in corals from the island of Tobago: Not simply a record of the Orinoco. Proc 10th Int Coral Reef Symp 1:580-587

Muscatine L, Weis V (1992) Productivity of zooxanthellae and biogeochemical cycles. In: Falkowski PG, Woodhead AD, Vivirito K (eds) Environmental science research; Primary productivity and biogeochemical cycles in the sea. SpringerVerlag, New York, pp 257-271

Nothdurft LD, Webb GE, Buster NA, Holmes CW, Sorauf JE, Kloprogge JT (2005) Brucite microbialites in living coral skeletons: Indicators of extreme microenvironments in shallow-marine settings. Geol 33(3):169-172

Omata T, Suzuki A, Kawahat H, Okamoto M (2005) Annual fluctuations in the stable carbon isotope ratio of coral skeletons: The relative intensities of kinetic and metabolic isotope effects. Geochim Cosmochim Acta 69:3007-3016

Paillard DL, Labeyrie L, Yiou P (1996) Macintosh program performs time-series analysis. Eos Trans AGU 77:379

Pätzold J (1984) Growth rhythms recorded in stable isotopes and density bands in the reef coral Porites lobata (Cebu, Philippines). Coral Reefs 3:87-90 
Porter JW, Fitt WK, Spero HJ, Rogers CS, White MW (1989) Bleaching in reef corals - physiological and stable isotopic responses. Proc Natl Acad Sci USA 86:9342-9346

Rodrigues LJ, Grottoli AG (2006) Calcification rate and the stable carbon, oxygen, and nitrogen isotopes in the skeleton, host tissue, and zooxanthellae of bleached and recovering Hawaiian corals. Geochim Cosmochim Acta 70:2781-2789

Rodriguez-Roman A, Hernandez-Pech X, Thome PE, Enriquez S, Iglesias-Prieto R (2006) Photosynthesis and light utilization in the Caribbean coral Montastraea faveolata recovering from a bleaching event. Limnol Oceanog 51:2702-2710

Schlichter D, Zscharnack B, Krisch H (1995) Transfer of photoassimilates from endolithic algae to coral tissue. Naturwissenschaften 82:561-564

Shashar N, Stambler N (1992) Endolithic algae within corals: Life in an extreme environment. J Exp Mar Biol Ecol 163:277-286

Smith JM, Quinn TM, Helmle KP, Halley RB (2006) Reproducibility and climatic signals in the Atlantic coral Montastraea faveolata. Paleoceanography 21:PA1010

Suzuki A, Gagan MK, Fabricius K, Isdale PJ, Yukino I, Kawahata H (2003) Skeletal isotope microprofiles of growth perturbations in Porites corals during the 1997-1998 mass bleaching event. Coral Reefs 22:357-369
Swart PK (1983) Carbon and oxygen isotope fractionation in scleractinian corals: a review. Earth-Sci Rev 19:51-80

Swart PK, Leder JJ, Szmant AM, Dodge RE (1996) The origin of variations in the isotopic record of scleractinian corals 2: Carbon. Geochim Cosmochim Acta 60:2871-2885

Titlyanov EA, Kiyashko SI, Titlyanova TV, Kalita TL, Raven JA (2008) $\delta^{13} \mathrm{C}$ and $\delta^{15} \mathrm{~N}$ values in reef corals Porites lutea and $P$. cylindrical and their epilithic and endolithic algae. Mar Biol 155:353-361

Tribollet AC, Langdon C, Golubic S, Atkinson M (2006) Endolithic microflora are major primary producers in dead carbonate substrates of Hawaiian coral reefs. J Phycol 42:292-303

Weber JN, Deines P, Weber PH, Baker PA (1976) Depth related changes in the carbon-13 carbon-12 ratio of skeletal carbonate deposited by the Caribbean reef frame building coral Montastrea-annularis further implications of a model for stable isotope fractionation by scleractinian corals. Geochim Cosmochim Acta 40:31-39

Wegley L, Yu Y, Breitbart M, Casas V, Kline DI, Rohwer F (2004) Coral-associated archaea. Mar Ecol Prog Ser 273:89-96

Wilkinson C (ed) (2000) Status of coral reefs of the world: 2000. Australian Institute of Marine Science, Townsville, QLD (Australia), p 363 